Revista Vernáculo, nº 14 - 15 - 16, pp. 21 - 50.

\title{
LEGISLAÇÃO PORTUGUESA E FORMAÇÃO DE ELITES POLÍTICAS LOCAIS: JUÍZES E VEREADORES DA CÂMARA MUNICIPAL DE CURITIBA - SÉCULO XVIII
}

Isis Messias da Silva ${ }^{1}$

Resumo: Este artigo é fruto de minha monografia de conclusão de curso, Pelouros e Barretes: juízes e vereadores da Câmara Municipal de Curitiba - Século XVIII, que contou com o financiamento do CNPq. Esta pesquisa destacou a importância das câmaras municipais no Brasil Colonial como instrumento privilegiado para se compreender as relações entre metrópole e colônia. Nesse sentido, foi imprescindível discutir como se realizava o processo da escolha de seus membros. Tendo como objeto a Câmara Municipal de Curitiba, e abrangendo o período de 1693 a 1828, recorremos às Atas de Vereações, às Atas de Eleições Municipais e aos Termos de Posse e Juramento para identificar os oficiais eleitos "por barrete". Inicialmente levantou-se a composição anual da câmara, e, também a ocorrencia das eleições de barrete. Foram, então elaboradas biografias dos envolvidos na administração local. Concluimos, entre outras questões que, as eleições de barrete apresentaram-se como fator facilitador da repetição dos indivíduos nos cargos da câmara no período estudado.

Palavras-chave: Elites Políticas Locais; Eleições de Barrete; Brasil Colonial Curitiba Setecentista.

\section{Introdução}

Considerando que dentre os vários questionamentos levantados pelos historiadores que se dedicam ao estudo das municipalidades está a administração local e, mais precisamente, a autonomia das câmaras municipais, devemos destacar a importância das câmaras municipais como instrumentos privilegiados para se compreender, através do estabelecimento de elites políticas locais e do exercício do poder pelas mesmas, as relações entre metrópole e colônia.

Com relação à administração local, a escolha dos membros das câmaras municipais apresenta-se como um dos aspectos fundamentais de seu

\footnotetext{
${ }^{1}$ Graduanda em História (Universidade Federal do Paraná)
} 
funcionamento. Desse modo, discutir como se realizava esse processo, tratando da qualidade das pessoas que compunham a câmara, torna-se imprescindível.

Nesse sentido, discutimos um tipo de processo eleitoral para a ocupação dos ofícios da Câmara Municipal de Curitiba: as eleições de barrete ${ }^{2}$. Estas eleições eram um processo eleitoral distinto do mais comum (e recomendado), as eleições de pelouros, ${ }^{3}$ as quais tinham a participação do povo e dos Homensbons ${ }^{4}$, escolhendo indiretamente, através de seis eleitores (dentre os Homensbons), os oficiais da câmara. $\mathrm{O}$ andamento das eleições de barrete era menos complicado; no entanto, não pode ser considerado menos importante. Delas participavam apenas os membros da Câmara (em alguns casos, também os oficiais que já haviam servido), pois seu propósito era escolher alguém para suprir a ausência de algum dos eleitos nos pelouros. Segundo as Ordenações, se a pessoa,

se a pessoa, que em algum pelouro sair, for fallecida, ou absente, de maneira que se não spere vir cedo, ou for impedido de impedimento prolongado, juntar-se-hão os Officiaes da Camera com os homens bons, que nos pelouros della soem andar, e às mais vezes escolherão quem servirá o Officio em lugar do morto, absente ou

\footnotetext{
${ }^{2}$ Eram chamadas eleições de barrete aquelas que ocorriam durante um ano não eleitoral para o preenchimento de um cargo na câmara de vereadores. Eram assim conhecidas porque os votantes depositavam papéis com o nome de seu candidato em um barrete, ou um saco de pano, para que então um desses fosse sorteado e assumisse a função vaga.

${ }^{3}$ Pelouro era o tipo de eleição indicado pela legislação portuguesa. Em bolas de cera, eram reunidas as listas com os nomes dos homens que, em tese, fariam parte da composição da câmara nos três anos seguintes. Essas bolas eram guardadas em um saco de couro ou de pano que ficava depositado em um cofre até que, na ocasião adequada, fosse aberto para que se tornasse do conhecimento de todos, quais seriam os novos membros da câmara municipal.

${ }^{4}$ Segundo as leis portuguesas, os únicos indivíduos aptos a representarem a Coroa, eram aqueles que, por sua posição social, dessem garantias de idoneidade e de comprometimento com a monarquia. A liderança local cabia às principais pessoas dos concelhos, aos membros das mais antigas, nobres e ricas famílias, pois estas disporiam de uma autoridade natural, além de garantirem isenção no exercício de seus ofícios. Assim, os chamados Homens bons deveriam ser moradores locais e possuidores de bens de raiz, retirando da terra suas rendas. Legal e formalmente, portanto, estavam excluídos desta categoria judeus, oficiais mecânicos e, no caso da América Portuguesa, degredados. Entretanto, a riqueza foi um critério acrescido à hereditariedade para fazer-se parte da governança. GOUVÊA, Maria de Fátima Silva. Os homens da governança no Rio de Janeiro em fins do século XVIII e início do XIX. In: VIEIRA, A. O Município no Mundo Português. Funchal: Centro de Estudos de História do Atlântico, 1998.
} 
impedido, enquanto durar a absencia, ou o impedimento. E esta mesma maneira se terá, quando depois de começar a servir o Official, fallecer, ou se absentar, ou for impedido. E a este, que assi elegerem, darão em Camera juramento, que bem e verdadeiramente sirva o tal Officio. ${ }^{5}$

Quanto à documentação utilizada para verificar o funcionamento do processo de eleição de barrete, servimo-nos das Atas de Eleições, ${ }^{6}$ dos Termos de Posse e Juramento e das Atas de Vereações ${ }^{7}$ produzidas no período de 1693 a 1828.

No tocante às balizas temporais, a primeira data (1693) corresponde ao ano da eleição dos primeiros ocupantes da Câmara Municipal de Curitiba, e a última (1828) refere-se à edição da lei que, no período imperial brasileiro, "dá nova forma às câmaras municipais, marca suas atribuições e o processo para a sua eleição e dos juízes de paz", ${ }^{8}$ alterando, portanto, o processo até então utilizado.

A documentação produzida pela Câmara Municipal de Curitiba no período de 1693 a 1828, ofereceu condições de arrolar e, posteriormente, identificar os ocupantes dos principais cargos da Câmara Municipal de Curitiba: juízes ordinários, vereadores, procuradores e juízes de órfãos. Após a identificação dos ocupantes destas funções, reunimos dados considerados

\footnotetext{
${ }^{5}$ ORDENAÇÕES FILIPINAS, Livro I, § 6, tit. 67.

${ }^{6}$ Livro de Atas de Eleições (1748 - 1758) - Manuscrito; Biblioteca da Câmara Municipal de Curitiba. Livro de Atas de Eleições (1765 - 1827) - Manuscrito; Biblioteca da Câmara Municipal de Curitiba.

7 Termos de Posse e Juramento e Atas de Vereações - Documentação transcrita In: NEGRÃO, Francisco (ed.). Boletins do Archivo Municipal de Curityba. Curitiba: Câmara Municipal, 1906 -, 64 volumes. Fizemos uso dos exemplares expostos para consulta local na Biblioteca Pública do Paraná, encontrados em avançado estado de deterioração pelo tempo e clima, e na Biblioteca do Setor de Ciências Humanas e Educação da Universidade Federal do Paraná - UFPR, os quais se apresentaram em melhor estado, porém não deixando de estar em lastimáveis condições de preservação, causadas pelo mau uso dos freqüentadores da mesma que parecem não ter hesitado em fazer anotações (a lápis ou caneta) nas margens, rasgar ou mesmo arrancar páginas dos livros.

${ }^{8}$ No Regimento das Câmaras Municipais do Império, Lei de $1^{\circ}$ de outubro de 1828 , uma das alterações sofridas é a perda da atribuição judiciária das câmaras. CAMPANHOLE, A. e CAMPANHOLE, H. L. (comp.) Constituições do Brasil. São Paulo: Atlas, 1989. 10 ed. p. 785 - 796. APUD: SANTOS, Rosângela Maria Ferreira dos. Eleições Municipais no Brasil Colonial: Curitiba, 1735 - 1765. Curitiba, 2002. Monografia (Bacharelado em História) Universidade Federal do Paraná.
} 
relevantes para a elaboração de uma biografia sobre a vida política dos indivíduos que fizeram parte da governança.

Passamos então a verificar de que forma aconteciam as eleições de barrete na Câmara Municipal de Curitiba e a identificar os participantes, especialmente os responsáveis pela eleição dos oficiais. Pudemos, então, determinar com que freqüência eram realizadas as eleições de barrete e definir os motivos que levavam a tal procedimento.

Com a realização desse trabalho, através da interpretação das informações coligidas referentes aos indivíduos constantes de nossa relação, estabelecemos, o que esperamos ser, para a composição da Câmara Municipal de Curitiba no século XVIII, um paradigma geral de análise. Entendemos que as características dos indivíduos que pudemos localizar desempenhando funções na administração da municipalidade estudada permitem discutir a formação de elites políticas locais. Nesse sentido, porquanto muitos dos envolvidos na administração local eram portadores de títulos militares, corroborou-se a hipótese de que o acesso aos cargos da governança facilitava a aquisição de títulos de nobreza e agregava ao indivíduo prestígio social, concluindo pela existência de uma relação unívoca entre títulos honoríficos e militares e elites políticas locais.

\section{Eleições municipais e formação de elites políticas locais}

A vila de Curitiba, localizada acima da Serra do Mar, delimitada apenas ao norte por Sorocaba e a leste por Paranaguá, começou a formar-se em meados do século XVII, tendo como primeiros estabelecimentos os arraiais de mineradores. Segundo Magnus Pereira e Antonio Cesar de Almeida Santos, a fundação da vila de Curitiba se deu através de um processo que teve seu ponto inicial na ereção de uma capela por volta de 1650, como marco delimitador entre a "cristandade e a barbárie circundante" ". No ano de 1668, ocorreu a primeira concessão de sesmaria de terras na região de Curitiba, a qual foi feita pelo Capitão-mor da vila de Paranaguá, Procurador do Marquês de Cascais (donatário da Capitania), Gabriel de Lara, em favor de Mateus Martins Leme. No mesmo ano temos a tomada de posse da povoação e a petição que resultou no levantamento do pelourinho pelo Capitão Gabriel de Lara. ${ }^{1{ }^{3}}$

\footnotetext{
${ }^{9}$ PEREIRA, Magnus Roberto de Mello; SANTOS, Antônio Cesar de Almeida. O poder local e a cidade: a Câmara Municipal de Curitiba, séculos XVII a XX. Curitiba: Aos Quatro Ventos, 2000. p. 22.

${ }^{10}$ Ver por exemplo: NEGRÃO, Francisco. Efemérides Paranaenses. Curitiba: Circulo de Estudos Bandeirantes, v. 1 e 2, 1949. p. 619; NEGRÃO, Francisco. Memória Histórica
} 
Contudo, ocorreu um lapso de 25 anos entre o levantamento do pelourinho e a elevação do povoado à categoria de vila, com a instalação de uma câmara de vereadores. A câmara estaria encarregada de dissociar o espaço urbano do rural, ordenando o território através da supervisão das construções, da elaboração de regras de habitação e higiene, da regulação dos hábitos dos moradores locais para garantir a convivência e a segurança. Assim, em 1693, Mateus Martins Leme, designado Capitão povoador dos campos de Curitiba, e representante do Marquês de Cascais, deferiu requerimento dos moradores da povoação de Nossa Senhora da Luz dos Pinhais para que fosse elevado o povoado à condição de vila e fossem criadas as justiças ordinárias. No dia 29 de março de 1693, ocorreu a instalação da vila de Nossa Senhora da Luz dos Pinhais, dos campos de Curitiba, e a eleição dos primeiros juízes ordinários, vereadores e procurador do Município. Na ocasião, foram eleitos Antonio da Costa Veloso e Manuel Soares, como juízes; Garcia Rodrigues Velho, Capitão José Pereira Quevedo e Antonio dos Reis Cavaleiro, como vereadores; Capitão Aleixo Leme Cabral, como procurador, e o ofício de escrivão foi ocupado por João Rodrigues Seixas.

De acordo com Magnus Pereira e Antonio Cesar de Almeida Santos, Curitiba era uma localidade de fronteira, na "periferia da periferia". Contudo, nela é reproduzido todo o aparato político-administrativo próprio do município português, revelando, através desse aspecto da colonização portuguesa, a (pelo menos parcial) eficiência da Coroa em se fazer presente e atuante nos territórios conquistados. ${ }^{11}$ No entanto, a instância do poder local como extensão ou braço da Coroa e suas relações com o esse poder central, precisam ser discutidas.

A política administrativa portuguesa, no que concerne à organização municipal, tanto na metrópole quanto na colônia brasileira, remonta ao modelo romano, o qual perdura, pelo menos, até o final da monarquia. ${ }^{12}$ Posteriormente à formação do Estado Nacional português, consolidado por volta de 1383-85, com a Revolução de Avis, a economia passou a reorganizar-se em torno dos interesses da burguesia comercial e dos centros urbanos, nos quais a administração era exercida por concelhos locais, espécie de assembléias que deliberavam sobre as

Paranaense. Curitiba, s/d. p. 55; PEREIRA, Magnus Roberto de Mello; SANTOS, Antônio Cesar de Almeida. O poder local..., p. 22.

${ }^{11}$ PEREIRA, Magnus Roberto de Mello; SANTOS, Antônio Cesar de Almeida. op. cit., p. 28.

${ }^{12}$ Ver, entre outros, SALGADO, Graça (org.). Fiscais e Meirinhos: a administração no Brasil colonial. Rio de Janeiro: Nova Fronteira, 1985. 
necessidades da comunidade, como o conserto e construção de estradas, de igrejas, de praças, organização de feiras de comércio etc.

$\mathrm{O}$ expansionismo marítimo português derivou de uma convergência de interesses da burguesia e do Estado, deslocando o eixo econômico do Mediterrâneo para o Atlântico e, conseqüentemente, propiciando a ocupação, colonização e exploração das ilhas do norte do Atlântico e do Brasil. A burguesia, assim, consolidava-se como grupo determinante na política e na economia, compondo majoritariamente os concelhos visto que eram os seus interesses que estavam concentrados nas cidades. O desenvolvimento da economia fez com que os ricos comerciantes começassem a conquistar postos antes apenas ocupados por nobres. ${ }^{13}$

Todavia, a Coroa também estava presente nas povoações. Desde a época medieval, os reis portugueses nomeavam um fidalgo para atuar junto aos concelhos. Este fidalgo ficava responsável pela defesa da praça, e recebia a designação de alcaide. Este tipo de nomeação evidenciava a necessidade de representantes do poder régio em cada localidade, pois se fazia necessário que, em todos os seus domínios, o poder régio estivesse simbolicamente presente, defendendo e ordenando territórios e populações. No entanto, o exercício de poderes cedidos a agentes acabaria por ser incorporado por estes às suas próprias pessoas, tendendo a administração local a concentrar-se nas mãos de clãs familiares que, cada vez mais, defendiam causas próprias em detrimento dos interesses da Coroa. No sentido contrário, a Coroa desenvolvia mecanismos para melhor fiscalizar e controlar seus agentes e as diversas instâncias de poder, como, por exemplo, as disposições contidas nas Ordenações Filipinas (1603), a partir das quais diversos aspectos da administração municipal foram reorganizados e padronizados.

Com relação à administração municipal, esta era organizada em câmaras municipais, seus responsáveis exerciam funções político-administrativas, fazendárias e policiais. Compunham-nas três vereadores, um procurador e dois juízes ordinários, um dos quais acumulava a função de presidente da câmara. Entre suas competências estavam a conservação dos serviços básicos prestados à população, a regulação do abastecimento de gêneros e de água, a definição e fiscalização dos preços e condições do comércio, a fiscalização da higiene pública, o zelo pelas condições de salubridade, a organização de festas religiosas. Além destas competências, os membros da câmara deveriam fiscalizar uns aos

${ }^{13}$ KUZNESOF, Elizabeth Anne. A família na sociedade brasileira: parentesco e estrutura social (São Paulo, 1700 - 1890). Revista Brasileira de História. São Paulo, v. 9, n. 17, set/88-fev/89. passim. 
outros, advogar queixas populares, definir como se aplicaria a receita, verificar as contas do procurador anterior, nomear outros oficiais como os almotacés.

No entanto, os municípios do mundo português não eram todos iguais, nem tinham todos a mesma autonomia em relação ao poder central. Existiam dezenas de modelos administrativos distintos, pois estes se adequavam às características econômicas, de formação, tamanho e população de cada região. Segundo Odair Rodrigues Alves, aos municípios nos quais havia magistrados, a historiografia lusa atribuiu a alcunha de "perfeitos"; àqueles em que os magistrados inexistiam, "imperfeitos". Contudo, Alves reconhece que dentro dessa divisão entre municípios "perfeitos" e "imperfeitos" havia muitas particularidades determinadas de acordo com a região e os costumes da população e que essas não se limitavam apenas às características administrativas, mas também à composição social de cada localidade. ${ }^{14}$

É exatamente com relação à autonomia das câmaras municipais ${ }^{15}$ que os mais recorrentes questionamentos são levantados pelos historiadores que se dedicam ao estudo da administração local. Essa discussão deve-se, em parte, ao fato de que, nos séculos XVII e XVIII, a Coroa portuguesa intensificou a criação e aplicação de mecanismos fiscalizadores e controladores, buscando assim uma mais efetiva centralização do poder. No Portugal medieval, a função do rei era, no essencial, manter as jurisdições; com o passar dos séculos, aumentaram as atividades administrativas da Coroa, e o monarca passa a ser o mantenedor do equilíbrio do corpo social, "atribuindo a cada um aquilo que lhe era próprio, garantindo assim a justiça". ${ }^{16}$ Sobre esse aspecto é exemplar a criação dos juízesde-fora, em 1696, que eram nomeados pelo rei para atuarem junto às câmaras municipais. A administração portuguesa mescla às características herdadas da antiguidade (como os diferentes tratamentos dados aos diversos municípios) às formas árabes de administração, pelas quais foi gerida no período da ocupação

${ }^{14}$ Conferir, por exemplo: ALVES, Odair Rodrigues. O município: dos romanos à Nova Republica. São Paulo: Companhia Editora Nacional, 1986. AZEVEDO e SILVA, José Manuel. O processo de municipalização na Amazónia. Aspectos particulares da Vila de Vigia. In: VIEIRA, A. op. cit.

${ }^{15}$ Por volta do século XI assiste-se à passagem do concelho à câmara. Enquanto aquele era realizado em local aberto, em praça pública, as câmaras municipais eram espaços fechados nos quais as reuniões ocorriam de forma secreta. COELHO, Maria Helena da Cruz. MAGALHÃES, Joaquim Romero. O Poder Concelhio: das origens às cortes constituintes. Notas da História Social. Coimbra: Centro de Estudos e Formação Autárquica, 1986.

${ }^{16}$ BICALHO, Maria Fernanda Baptista. O que significa ser cidadão nos tempos coloniais. In: ABREU, Martha; SOIHET, Rachel. Ensino de História: conceitos, temáticas e metodologias. Rio de Janeiro: Casa da Palavra, 2003. p. 140. 
moura (como, por exemplo, a de inspecionar e regular os preços, pesos e medidas nos mercados, atribuição dos almotacés). ${ }^{17}$

Autores, como Luís Vidigal, ${ }^{18}$ por exemplo, indicam que escritores do século XIX (citando explicitamente Alexandre Herculano) e autores do século $\mathrm{XX}$ incorreram em erro ao exagerarem no poder que cabia aos municípios, transformando-os em pequenos Estados "presos por amarras ao poder central". Obviamente, Vidigal reconhece que parte do poder acabava por ser delegado aos municípios e aos que os administravam, contudo isso sendo permitido pela Coroa, uma vez que não havia outra forma de governá-los. Para Vidigal, esses "equívocos" são provocados pela análise de situações pitorescas provocadas pela consulta de escassas fontes, quando o ideal seria reunirmos um maior número de fontes para podermos concluir dados relevantes entre o local e o central.

Segundo Vidigal, a legislação que determinava quem poderia exercer uma função administrativa local permitia a formação de uma "oligarquia camarária". Esta se constituía de uma nova classe, formada por meio de um processo político-ideológico de homogeneização, definindo uma identidade comum, de uma mescla dos baixos escalões da nobreza e da burguesia ascendente. A essa nova classe conferia-se o título de "nobreza camarária" ou "da terra", devido à definição das Ordenações Filipinas de titular-se honorificamente aqueles que ocupassem cargos de vereador, juiz ordinário e procurador. ${ }^{19}$ Marcada pela interdependência, determinante para a identificação dos núcleos oligárquicos, pretendia preservar os municípios da influência dos verdadeiros nobres pelo favorecimento entre eleitores e eleitos.

Para executar uma função administrativa, o indivíduo poderia comprar o cargo, ser designado pelo soberano, ou preenchê-lo por meio de eleições. ${ }^{20}$ Os cargos das câmaras eram eletivos, definidos de forma indireta. No processo eleitoral, eram escolhidos pelo povo e pelos Homens bons seis eleitores dentre os Homens bons. Estes eleitores, separados em duplas, escolheriam, três grupos de seis homens que, pelos próximos três anos, estariam à frente da câmara, com mandatos de um ano cada. No caso de um dos membros não poder assumir seu posto, era realizada outra eleição, da qual participavam somente integrantes ou ex-integrantes da câmara, para suprir aquela ausência.

Para Nuno Gonçalo Monteiro, o exercício dos poderes locais está relacionado ao processo de estruturação das elites, sendo o modelo oligárquico o

${ }^{17}$ COELHO, Maria Helena da Cruz. MAGALHÃES, Joaquim Romero. op. cit.,

${ }^{18}$ VIDIGAL, Luís. O Municipalismo...passim.

${ }^{19}$ VIDIGAL, Luis. No microcosmo...

${ }^{20}$ VIDIGAL, Luis. O Municipalismo... 
modelo oficial. ${ }^{21}$ De modo semelhante, José Viriato Capela afirma que as elites locais são as estruturadoras do poder local, da sociedade local, contribuindo assim para a formação do Estado e da sociedade administrativa como um todo. Todavia, Capela aponta para a questão do ressurgimento de estudos sobre as elites, porém equivocados, sem sistemática, como já apontou Luís Vidigal, sem correlação com o exterior, fechados sobre si mesmos. ${ }^{22}$

Para Vidigal, a ordenação dos poderes locais serve para enquadrar as lutas grupais e caracterizar a natureza dos poderes locais e centrais, sendo o poder local o espaço de confronto e de triunfo da modernidade das classes liberais sobre a sociedade de estados. ${ }^{23}$

Ainda no que se refere ao exercício de cargos concelhios, apesar do rigor da legislação, nem sempre ela era observada. Segundo Azevedo e Silva, as particularidades de cada região, as características das populações coloniais e a distância do Reino foram fatores que possibilitaram ou fizeram necessário, no Brasil e em outros domínios ultramarinos, o descumprimento de normas gerais da legislação portuguesa. ${ }^{24}$ Também do ponto de vista das populações concelhias, deve-se considerar que os indivíduos envolvidos com a administração local eram atraídos para o exercício dos cargos municipais pelos benefícios materiais e sociais que estes poderiam proporcionar. Contudo, nos municípios rurais de baixa renda, o ônus acarretado pelo exercício dos cargos afastava o interesse das elites dos mesmos. ${ }^{25}$ Maria de Fátima Silva Gouvêa destaca que a ocupação de um cargo na administração local facilitava o acesso a títulos militares, de ordens religiosas e honoríficos, além de garantir o reconhecimento por parte da sociedade como homens de importância, passando a ocupar posições de destaque nas festas e atos públicos. ${ }^{26}$ Contudo, a ascensão à governança de uma terra tinha eficácia somente local, atraindo então, principalmente, as casas com pouca perspectiva de mobilidade social. As famílias mais afortunadas, porém, tinham pretensões de serviço à monarquia e a alianças, inclusive matrimoniais em outras províncias, escusando-se assim de exercer os cargos municipais. ${ }^{27}$

\footnotetext{
${ }^{21}$ MONTEIRO, Nuno Gonçalo. Poderes Municipais e elites locais (séculos XVIII - XIX): estado de uma questão. In: VIEIRA, A. op. cit.

22 CAPELA, José Viriato; BORRALHEIRO, R. As elites do norte de Portugal na administração municipal (1750 - 1834). In: VIEIRA, A. op. cit.

${ }^{23}$ VIDIGAL, Luis. No microcosmo...passim.

${ }^{24}$ AZEVEDO e SILVA, O processo...

${ }^{25}$ CAPELA, José Viriato, BORRALHEIRO, R As elites do norte...

${ }^{26}$ GOUVÊA, M. F. S. op. cit.

${ }^{27}$ MONTEIRO, Nuno Gonçalo. Poderes...
} 
Maria de Fátima Silva Gouvêa afirma ainda que o espaço do poder local é o principal para o estabelecimento das relações entre metrópole e colônia no século XVIII, e que, exatamente por isso, os colonos eram atraídos a tomar parte na gestão colonial. No entanto, para a realidade que estuda, afirma que os Homens bons eram um grupo deveras pequeno, considerando-se aqueles que realmente ocuparam os cargos, contudo para nossa realidade veremos que o conceito de Homens bons era adaptável e que em realidade não era um grupo tão pequeno assim. ${ }^{28}$

Durante o Antigo Regime português, apesar dos esforços despendidos pela Coroa para a construção de um estado absoluto, os poderes locais mantiveram-se, em determinados aspectos, autônomos. ${ }^{29}$ A mais explícita manifestação da autonomia local era a legislação produzida nessa instância de poder, as posturas. Essas leis eram uma forma de adaptar a legislação geral do reino às necessidades e costumes locais. As posturas municipais eram uma herança da tradição medieval portuguesa, e representam a passagem da oralidade para o estabelecimento de códigos administrativos escritos. Somente as câmaras poderiam criá-las, suprimi-las ou aplicá-las. Todavia, eram submetidas ao poder central para que, verificada sua concordância com as normas gerais, tivessem a efetividade desejada. ${ }^{30}$

As câmaras municipais e o poder central não defendiam, entretanto, interesses absolutamente antagônicos. Em dadas ocasiões, as lideranças locais estavam em plena harmonia com as determinações régias; em outras, na mais absoluta discórdia, dependendo de como os interesses da Coroa afetassem os seus. Segundo Caio Prado Jr., no Brasil colônia, a ação das câmaras foi maior que a estabelecida nas leis, sendo o domínio da metrópole simplesmente teórico, gozando as câmaras de autonomia considerável. ${ }^{31}$ Para Caio Prado Jr., o poder econômico e político da colônia estava concentrado nas mãos dos proprietários rurais que, preocupados em defender seus interesses, prejudicavam a população das vilas e ofuscavam "a própria soberania teórica da Coroa". Deste modo, no Brasil, a administração municipal, organizada sobre bases rurais, seria "a

${ }^{28}$ GOUVÊA, M. F. S. op. cit.

${ }^{29}$ SOARES, Sérgio Cunha. Aspectos da política municipal pombalina: a câmara de Viseu no reinado de Dom José. Revista portuguesa de História. T. 21. Faculdade de Letras da Universidade de Coimbra, 1984.

${ }^{30}$ Conferir, por exemplo: VIDIGAL, Luis. O Municipalismo...; PEREIRA, Magnus Roberto de Mello.As posturas municipais e o controle do processo edificatório. Monumenta, Segunda série, v. 2, n. 7, 1999, p. 03 - 28.

${ }^{31}$ PRADO Júnior, Caio. Evolução política do Brasil e outros estudos. 4. Ed. São Paulo: Brasiliense, 1963. p. 28. 
verdadeira e quase única administração da colônia". ${ }^{32}$ O poder municipal seria um instrumento ao serviço dos notáveis locais (nobres e proprietários) regulamentando em proveito próprio, a vida dos conselhos. A autonomia indicada por Prado Jr. havia sido afirmada anteriormente por João Francisco Lisboa, que a entendia como decorrente do "estado excepcional e irregular em que sempre estiveram as colônias (onde) acharemos a explicação dessas pretensões, aliás, tantas vezes coroadas do êxito mais completo". ${ }^{33}$

Raymundo Faoro entende que a administração portuguesa, contrariamente ao entendimento de Caio Prado Jr., era um "sistema coeso e racional em que o rei a tudo provia, (e) reduzia o funcionário colonial à dimensão de mera sombra". ${ }^{34}$ Faoro crê que a autonomia dos municípios era tolerada, pois estes, dotados de "efêmera dignidade", eram simples auxiliares do governo central, sem liberdade de ação. Aliás, como já indicado, as representações locais do poder régio eram necessárias para a manutenção da integralidade do território.

Nesta discussão, deve-se ainda indicar a posição de Capistrano de Abreu, para quem as câmaras municipais coloniais nunca deliberaram sobre questões importantes, considerando-as órgãos de administração local, cuja importância nunca pesou decisivamente, nem no Reino nem aqui. ${ }^{35}$

Mais recentemente, Laura de Mello e Souza procurou desembaraçar essa discussão, afirmando que o poder local jamais se insurgiu contra o poder central, servindo-o e beneficiando-se do mesmo: "assim sendo, a administração serviu, em primeiro lugar, à Metrópole, e depois, na medida em que havia consonância de interesses, aos Homens bons, uma verdadeira oligarquia, perfeitamente inserida na estrutura de poder. Tratava-se, portanto, de um grupo poderoso que só

\footnotetext{
${ }^{32}$ PRADO Júnior, id.

${ }^{33}$ LISBOA, João Francisco. Crônica do Brasil Colonial: apontamentos para a história do Maranhão. Petrópolis: Editora Vozes, 1976. p. 389.

${ }^{34}$ FAORO, Raymundo. Os donos do poder: formação do patronato político brasileiro. 7 ed. Porto Alegre: Editora Globo, 1987. 2 v. p. 164.

35 "Nada confirma a onipotência das câmaras municipais descoberta por João Francisco Lisboa e repetida à porfia por quem não se deu ao trabalho de recorrer às fontes (...) dandolhe uma importância que nunca possuíram as municipalidades. “ABREU, João Capistrano de. Capítulos de História Colonial: $1500-1800$ \& Os caminhos antigos e o povoamento do Brasil. Brasília: Editora da Universidade de Brasília,1963. p. 154. Algumas dessas idéias a que se refere Capistrano de Abreu foram formuladas na época moderna, quando alguns autores outorgaram uma autonomia desmedida às câmaras municipais, acreditando serem as mesmas verdadeiros bastiões na luta contra a centralização do poder e o absolutismo. VIDIGAL, Luís. O Municipalismo...
} 
discordava da estrutura de poder quando se via afastado de seus privilégios". ${ }^{36} \mathrm{Ou}$ seja, as câmaras, mais do que focos de resistência ao poder central, foram a instância na qual, por vezes, coexistiam interesses divergentes. $\mathrm{O}$ modelo administrativo colonial era "consensual", participando os poderes locais na formação e consolidação dos poderes ultramarinos. ${ }^{37}$

Não obstante os diversos pontos de vista, há um ponto essencial e para o qual os autores acima referenciados convergem: as elites locais desenvolveram meios de fecharem-se e de restringirem o acesso a elas. Gouvêa, por exemplo, observa que os laços de parentesco recebiam maior destaque nos arrolamentos de elegíveis do que as ocupações materiais dos indivíduos. ${ }^{38}$ A família era a base do grupo social local e tornaram-se muito influentes fazendo da forte base familiar um sustentáculo do poder político. ${ }^{39}$ Embora este entendimento seja no mais das vezes aceito, é necessário discuti-lo, questionando, por exemplo, quem eram, então, os Homens bons de determinada comunidade e o que os diferenciava em relação aos demais moradores da mesma vila?

Considerando esse entendimento, é necessário também levar em conta que, no que diz respeito às colônias, a supervisão do Estado Português dessas povoações também está inserida no quadro institucional de centralização do poder buscado pela Coroa após a Restauração. Segundo Monteiro, "as monarquias pretendiam mais fortalecer as dinastias e impor sua autoridade que efetivamente centralizar o poder". ${ }^{40} \mathrm{Um}$ processo que ganha contornos mais nítidos no século XVIII, com os reinados de Dom João V (1706 - 1750) e Dom José I - e de seu Ministro, o Marquês de Pombal - (1750 - 1777). Ou seja, nestes reinados, a Coroa dedicou máximo zelo ao funcionamento institucional das vilas existentes, procurando melhor adequá-las à legislação portuguesa. ${ }^{41}$ Durante o período chamado Pombalino, as medidas tomadas pelo Estado tinham como objetivo afirmar sua autonomia e independência, tornando-o mais atuante, tutor de todo o país. Dada esta ação da Coroa, o espaço da administração municipal possibilita construir relações entre as realidades locais e o contexto mais amplo do Império

${ }^{36}$ SOUZA, Laura de Mello e. Desclassificados do ouro: a pobreza mineira no século XVIII. 2.ed. Rio de Janeiro: Edições Graal, 1982. p. 203.

${ }^{37}$ BICALHO, Maria Fernanda Baptista. op. cit. p. 142 et seq.

${ }^{38}$ GOUVÊA. op. cit.

${ }^{39}$ KUZNESOF, Elizabeth Anne. op. cit. passim.

${ }^{40}$ MONTEIRO, Nuno Gonçalo. Os Concelhos...p. 115.

${ }^{41}$ É necessário salientar que não havia legislação específica para os territórios coloniais, valendo-nos mesmos a legislação vigente na metrópole. 
Português, visto que as soluções adotadas para o governo dos negócios coloniais tinham como função responder às necessidades do Estado Central. ${ }^{42}$

Assim, com a reafirmação da importância dos poderes locais no contexto do Antigo Regime, a historiografia atual tem considerado que algumas intervenções do poder central nas normas que regulavam o preenchimento dos cargos municipais atuaram, ao mesmo tempo, no fortalecimento do Estado e das instituições locais. ${ }^{43}$ É nesse sentido, portanto, que o poder local - seu âmbito de atuação - apresenta-se como espaço privilegiado para o estudo das relações metrópole-colônia. ${ }^{44}$

Nesse sentido, discutir como se dava o processo de escolha dos membros das câmaras municipais, tratando também da qualidade das pessoas que as compunham, afigura-se como uma estratégia para nos aproximarmos do sentido, ou significado, das intervenções do poder central nas instâncias adjudicadas às câmaras municipais.

\section{Eleições de barrete em Curitiba no século XVIII}

No tocante à realização das eleições da Câmara Municipal de Curitiba, o exame de sua documentação tornou possível detectar que elas seguiam o padrão geral recomendado pelas Ordenações, especialmente após 1721, quando ocorreu a visita de correição do ouvidor geral de São Paulo, Rafael Pires Pardinho, que teve o intuito de regular e fiscalizar o bom funcionamento das instituições administrativas locais. A ação de Pardinho foi muito importante, e dentre os inúmeros aspectos institucionais que mereceram especial atenção desse ouvidor, estava a realização das eleições para os ofícios municipais, determinando que "no fazer das Eleysões dos officiais que ham de servir no Conc.o Guardem o tto 67 do mesmo Lb.o, recomendando também que 'não uzem mais Eleysam de hum anno como athe agora se fez', pois já havia bastantes pessoas para a Eleysam Trianal". ${ }^{45}$

Considerando-se que o exercício dos poderes locais está relacionado ao processo de estruturação das elites, ${ }^{46}$ torna-se imprescindível discutir o processo eleitoral e a escolha dos membros das câmaras, tratando da "qualidade" dos

\footnotetext{
${ }^{42}$ SALGADO, Graça (org.). op. cit. passim.

${ }^{43}$ CAPELA, José Viriato e BORRALHEIRO, R. op. cit. passim.

${ }^{44}$ GOUVÊA, M. F. S. op. cit.

45 NEGRÃO, Francisco (org.) Boletins do Archivo Municipal de Curityba. Curitiba: Câmara Municipal. 1906 - 1929, Vol VIII, p. 12.

${ }^{46}$ MONTEIRO, Nuno Gonçalo. Poderes...passim
} 
mesmos, como meio para a compreensão das relações entre metrópole e colônia no âmbito da administração local. Nesse sentido, através do levantamento das atas de vereação, atas de eleição e termos de posse e juramento transcritos nos Boletins do Arquivo Municipal de Curitiba, volumes I a XLII, pudemos identificar os indivíduos eleitos, tanto por pelouro quanto por barrete, e os respectivos cargos ocupados.

Após a visualização dessas diversas composições da Câmara curitibana entre os anos de 1693 e 1828, torna-se necessária a investigação das eleições de barrete propriamente ditas, somando aos dados já coletados os elementos encontrados nas transcrições dos Livros de Atas de Eleições. ${ }^{47}$

Com esses dados passamos a construir pequenas "histórias da vida administrativa" de cada indivíduo, ${ }^{48}$ acompanhando-os nas diferentes funções que ocuparam na Câmara Municipal de Curitiba.

A opção em privilegiarmos os eleitos na eleição de barrete deve-se ao fato de que tais indivíduos deveriam ser pessoas já conhecidas dos oficiais da câmara, ou seja, que mantinham relações sociais com o grupo que detinha os principais cargos da administração municipal. Lembremos que se tratava de uma

\footnotetext{
${ }^{47}$ As transcrições foram realizadas por Rosângela Maria Ferreira dos Santos, pesquisadora do Centro de Documentação e Pesquisa de História dos Domínios Portugueses, sécs. XV a XIX (CEDOPE), do Departamento de História da UFPR, e alcançam os seguintes originais: Livro de Atas de Eleições (1748 - 1758) - Manuscrito; Biblioteca da Câmara Municipal de Curitiba. Livro de Atas de Eleições (1765 - 1827) - Manuscrito; Biblioteca da Câmara Municipal de Curitiba. Estas Atas encontram-se transcritas e publicadas em SANTOS, Antônio Cesar de Almeida; SANTOS, Rosângela Maria Ferreira dos (org.). Eleições da Câmara Municipal de Curitiba (1748 a 1827). Monumenta. Curitiba: Aos Quatro Ventos, 2003. p. $33-256$.

${ }^{48}$ Para Giovanni Levi (Usos da biografia, Annales, 6, 1989), "nenhum sistema é de fato suficientemente estruturado para eliminar toda possibilidade de escolha consciente, de manipulação ou interpretação das regras. Assim, a biografia constitui o lugar para se verificar a liberdade de que as pessoas dispõem e para se observar como funcionam concretamente os sistemas normativos". Citado em FERREIRA, Marieta de Moraes. História oral: um inventário das diferenças. In: FERREIRA, Marieta de Moraes. (coord.). Entre-vistas: abordagens e usos da história oral. Rio de Janeiro: Ed. FGV, 1994, p. 7. "Nessa óptica, as biografias individuais só despertam interesse quando ilustram os comportamentos ou as aparências ligadas às condições sociais estatisticamente mais freqüentes. Portanto, não se trata de biografias verídicas, porém de uma utilização de dados biográficos para fins prosopográficos". LEVI, Giovanni. Usos da biografia. In: FERREIRA, Marieta de Moraes; AMADO, Janaína. (orgs.). Usos e abusos da história oral. Rio de Janeiro: Ed. FGV, 1996, p. 174.
} 
eleição na qual participavam somente os membros ou ex-membros da câmara para a escolha direta de um substituto.

A partir daí, trabalhando apenas com os indivíduos eleitos por barrete, passamos a descartar aqueles que tinham sido eleitos por barrete antes do ano de 1721, ano da correição do ouvidor Pardinho, pois entendemos que as eleições de barrete realizadas antes dessa data foram, de certo modo, realizadas pela "ignorância das normas". Contudo, o número de indivíduos não diminuiu muito: de 170 passou para 166. Compreendendo que não poderíamos trabalhar com tal montante de nomes, descartamos aqueles que haviam sido eleitos por barrete apenas uma vez - independente de quantas vezes o tinham sido nos pelouros entretanto, mantivemos dois deles, pois mantinham relações de parentesco com Lourenço de Andrade, indivíduo de comprovada importância para a sociedade local. Natural de Portugal, Lourenço de Andrade foi membro da câmara por oito vezes, em período anterior a 1721. Não temos como afirmar quantas e quais vezes foi eleito nos pelouros ou por barrete; em 1701, 1704, 1710 e 1714, exerceu funções que não nos foi possível definir, em 1706, 1707, 1708 e 1712 foi vereador.

Contávamos, então, 42 indivíduos. Destes, excluímos aqueles que haviam sido eleitos nos pelouros dez vezes ou menos, pois acreditamos que a quantidade de vezes que um indivíduo foi eleito nos pelouros pode ser um fator demonstrativo do prestígio de que gozaria entre seus iguais. Para fortalecer essa proposição, podemos salientar que, esses mesmos indivíduos teriam sido indicados para os cargos da câmara, maior número de vezes do que efetivamente os assumiram. Excluímos 31 indivíduos. Assim, tínhamos apenas 09 indivíduos, excetuando os 2 anteriormente selecionados com base em outro critério.

Devido à drástica diminuição de nosso universo demonstrativo, resolvemos "resgatar" 20 indivíduos excluídos nessa última etapa com base em dois critérios, o primeiro diz respeito à naturalidade: re-selecionamos 13 indivíduos naturais de outras partes do império colonial português que não o Brasil. Como a eleição para as funções administrativas era restrita aos naturais da terra, resolvemos analisar os motivos que levavam a esse descumprimento da legislação eleitoral. O segundo é, na verdade, a retomada de um critério já estabelecido anteriormente, reagrupamos 07 indivíduos sobre os quais conseguimos reunir dados biográficos que os ligavam aos outros anteriormente selecionados. Somam-se 31 indivíduos.

Iremos, a seguir, apresentar a relação dos indivíduos selecionados, os quais, em diferentes tempos e ocasiões, exerceram cargos de importância na Câmara Municipal de Curitiba. 
Primeiramente, relembraremos, de forma simplificada, os critérios de seleção utilizados na composição dessa listagem. Foram por nós relacionados os indivíduos:

a) eleitos, por pelouro e barrete, mais de dez vezes para as funções da câmara (foram 9 os indivíduos inscritos nesta situação);

b) sobre os quais conseguimos reunir dados que os ligavam aos anteriormente selecionados (tivemos 9 casos nesta situação);

c) que tinham como local de origem o reino ou outros domínios portugueses, visto que era proibido o acesso aos cargos da câmara para os que não eram naturais do lugar (encontramos 13 indivíduos).

Como alguns indivíduos agregaram mais de um dos critérios de seleção acima apontados, poderíamos relacioná-los de várias outras maneiras, como, por exemplo, do seguinte modo:

a) os que tivessem sido eleitos, por pelouro e barrete, mais de dez vezes para as funções da câmara (foram 8 os indivíduos inscritos nesta situação);

b) aqueles que tinham como local de origem o reino ou outros domínios portugueses, visto que era proibido o acesso aos cargos da câmara para os que não eram naturais do lugar (encontramos 15 indivíduos);

c) e, finalmente, os outros indivíduos sobre os quais conseguimos reunir dados que os ligavam aos anteriormente selecionados (tivemos 7 casos nesta situação).

Assim, ficariam 31 indivíduos, visto que, novamente, um deles agregou mais de um dos critérios de seleção. Esta lista serve para ilustrar a "qualidade" das pessoas que partilharam o poder local curitibano.

1. Antônio Álvares de Araújo (Comendador) - Foi eleito onze vezes sendo duas delas por barrete. $\mathrm{Na}$ data da primeira eleição tinha 53 anos e foi eleito procurador, na última, estava com 83 . Foi procurador nos anos de 1795, 1797,1810 e 1814 , sendo que nos anos de 1795 e 1814 foi eleito por barrete. Nos anos de 1801, 1812, 1815, 1819, 1820, 1821 e 1824 foi eleito vereador, todas às vezes nos pelouros. Segundo a Lista Nominativa de Habitantes de Curitiba, referente ao ano de 1765 , morava na região do Botiatuva, possuía uma arma, tinha 24 anos e era casado com Rita Ribeira Cardoza. Na Lista Nominativa de Habitantes de Curitiba referente ao ano de 1797, consta que era casado e tinha sete filhos.

2. Antônio Ferreira dos Santos - Eleito uma única vez para vereador por barrete em 1796, então contava 33 anos. Aparece nesta listagem por ter sido casado com Ana Maria de Andrade, neta de Lourenço de Andrade. 
Segundo a Lista Nominativa de Habitantes de Curitiba de 1787, tinha 24 anos, era casado, pai de dois filhos e senhor de um escravo.

3. Antônio Guedes de Carvalho - Eleito sete vezes, sendo quatro delas por barrete. Em 1778, foi eleito por barrete para procurador, quando tinha em torno de 34 anos. No ano de 1782, foi vereador sendo eleito nos pelouros e também por barrete. Foi por quatro vezes juiz ordinário em 1785 e 1795, por barrete, e em 1791 e 1797, por pelouro. Consta nesta listagem por ter sido casado com Isabel Rodrigues de Andrade, neta de Lourenço de Andrade. Segundo a Lista Nominativa de Habitantes de Curitiba referente ao ano de 1776 tinha 35 anos, era casado, tinha uma filha e 1 escravo. Era escrivão do eclesiástico e tinha, entre vacas e cavalgaduras, 4 animais. Na lista de 1777, aparece com 30 anos. Na Lista de 1783, consta que tinha 39 anos, era casado, pai de 3 filhos e senhor de 2 escravos A Lista do ano de 1787, relata que tinha 42 anos, casado, 5 filhos e 1 escravo. ${ }^{49}$

4. Antônio José de Andrade - Foi membro da câmara por seis vezes. Em 1768 e 1772, foi eleito vereador por barrete; em 1786, 1788,1793 e 1804, foi eleito juiz ordinário nos pelouros. Era neto de Lourenço de Andrade.

5. Antônio Martins Lisboa - Eleito para ocupar funções na câmara por treze vezes; assumiu doze delas (em 1769, quando foi eleito vereador alegou não enxergar bem por ser idoso, tinha então 61 anos). Foi eleito vereador pela primeira vez em 1734, quando tinha em torno de 33 anos, depois em 1741 e 1746, nos pelouros, e em 1757 e 1764 por barrete; eleito procurador por barrete em 1752, 1753 e 1755 e em 1757, por pelouro; foi; eleito juiz de órfãos em 1768. Na Lista Nominativa de Habitantes de Curitiba de 1765 , consta que morava no Botiatuva, tinha 59 anos, era casado com Paula Rodrigues, tinha um filho, e possuía 3 armas. Na lista do ano de 1776, aparece morando no bairro do Palmital, com 70 anos, viúvo, vivendo de suas lavouras e possuidor de vacas e cavalgaduras, além de 3 escravos. Tendo então um filho e uma filha, solteiros. Na Lista do ano seguinte, 1777, continua a aparecer como habitante do bairro do Palmital, contudo, a idade registrada é de 76 anos, possui ainda três escravos, vivendo com ele um filho e três filhas, um genro e duas netas. Para o ano de 1778, figura como habitante do bairro Bacacheri, com 78 anos, viviam com ele um escravo, um filho, três filhas, um genro e duas netas. Na Lista Nominativa de Habitantes de Curitiba do ano de 1787, consta morar na Roça Grande, ter 88 anos de

\footnotetext{
49 Muitas vezes, os dados informados nas listas nominativas mostraram-se conflitantes. Optamos, neste momento, apenas por registrá-los.
} 
idade, vivendo com ele um filho, três filhas, um genro e duas netas, além de dois escravos.

6. Antônio Ribeiro de Andrade (Capitão Mor) - Foi por cinco vezes membro da câmara municipal, sendo eleito duas delas por barrete (em 1820 foi eleito juiz ordinário por barrete, mas não assumiu). Foi vereador em 1781. Em 1799, 1800, 1808, 1815, (esta por barrete), foi juiz ordinário. Filho de Lourenço de Andrade. Casado com Francisca de Paula Carneiro, neta de Leão de Melo e Vasconcelos.

7. Antônio Teixeira de Freitas (Alferes) - Eleito para os cargos da câmara por quatro vezes. Foi eleito vereador por barrete em 1785, e nos pelouros em 1790 e 1794; eleito juiz ordinário por barrete em 1793. Neto de Lourenço de Andrade.

8. Bento Magalhães Peixoto - Natural de Portugal. Foi eleito para funções da câmara por cinco vezes. Foi eleito pela primeira vez para a função de vereador em 1756, por pelouro, quando já tinha 58 anos, depois em 1760, por barrete. Em 1757, foi eleito juiz ordinário. No ano de 1759 foi juiz de órfãos e em 1764 foi eleito por barrete para o cargo de procurador. Na Lista Nominativa de Habitantes de Curitiba do ano de 1765, consta que tinha 67 anos, cuidava de um enjeitado, e possuía 600 mil réis.

9. Estevão José Ferreira (Tenente) - Natural de Portugal. Cinco vezes membro da câmara municipal. Foi, em 1767, eleito por barrete para o cargo de procurador, tinha então 40 anos. Nos anos de 1773, 1777, 1779 e 1783, serviu como juiz ordinário, sendo em 1777 foi eleito por barrete. Na Lista Nominativa de Habitantes de Curitiba de 1777, figura com 50 anos de idade, casado, pai de 6 filhos e senhor de 4 escravos. Na Lista do ano seguinte (1778), aparece como senhor de seis escravos. No ano de 1791, teria nove escravos e apenas três de seus filhos morariam em sua casa. Segundo a Lista de 1793, seria senhor de sete escravos, e de um agregado de 23 anos. Na Lista do ano de 1797, figura como senhor de 8 escravos.

10. Felix Ferreira Neto (Sargento Mor) - Natural de Portugal. Eleito cinco vezes. Foi vereador nos anos de 1750, por pelouro e 1752, por barrete. Eleito para procurador nos anos de 1753 e 1754, ambas por pelouro; e para juiz ordinário (por barrete) no ano de 1757.

11. Francisco Linhares (Eclesiástico) - Natural de Portugal. Eleito três vezes para as funções da câmara. Foi eleito pela primeira vez para a função de vereador em 1769, por barrete, contando 45 anos. Depois, novamente eleito para vereador em 1773 e 1779, por pelouro. Vivia em concubinato e deixou dois herdeiros quando morreu em 1841. Na Lista de 1765, teria 40 anos. Na Lista de 1797, 74 anos de idade, dois agregados e um escravo. 
12. Francisco Marques Lameira - Natural de Portugal. Foi eleito por oito vezes. Foi eleito pela primeira vez em 1751 para a função de vereador, contava então 38 anos. Foi novamente eleito vereador em 1755, 1762, 1771, 1774 e 1778, por pelouro e em 1758, por barrete. Eleito juiz ordinário em 1768 (nos pelouros). Na Lista Nominativa de Habitantes de Curitiba de 1775, figura com 60 anos de idade, casado, com ele vivia seu filho. Na Lista do ano de 1777, aparece 67 anos, casado, habitando com ele seu filho e mais três escravos. No ano de 1787, 71 anos de idade, ainda casado e vivendo com sua esposa Josefa dos Santos e dois agregados, mais escravos.

13. Francisco Xavier Pinto (Sargento Mor) - Natural de Portugal. Eleito por oito vezes. Foi vereador por barrete em 1769. Nos pelouros saiu como juiz de órfãos em 1771 e como juiz ordinário nos anos de 1775, 1778, 1782, 1795. Em 1785 e 1788, foi novamente juiz ordinário, mas sendo eleito por barrete. Faleceu em 1805. Sogro de Joaquim Mariano Ribeiro Ribas.

14. Henrique Ferreira de Barros (Alferes) -Foi eleito oito vezes para ocupar os cargos da câmara. Em 1751 tinha 28 anos e foi eleito vereador. Foi procurador em 1754, por pelouro e em 1755, por barrete, mas não chegou a assumir. Eleito juiz de órfãos em 1759, por barrete e 1762, nos pelouros. Assumiu como juiz ordinário nos anos de 1760, 1772 e 1776, nos pelouros e em 1775, 1768 e 1778, por barrete. Na Lista de 1765, aparece casado com Francisca de Albuquerque, tendo 40 anos e dois filhos. Segundo a Lista de 1775, teria 52 anos, moraria no Tatuquara com seu filho, e seria viúvo. Na Lista do ano seguinte, 1776, aparece tendo 56 anos, vivendo de suas lavouras e possuindo, entre gado e cavalgaduras, 200 animais. Tinha então quatro filhas e um filho, que moravam com ele, além de um genro, três agregados e quatro escravos. Na Lista do ano de 1777, aparece com 57 anos, três filhos e três filhas, um genro, um neto e três agregados que viviam com ele.

15. Ignácio de Sá Souto Maior (Capitão) - Natural de Portugal. Eleito três vezes para os cargos da câmara. Foi eleito juiz em 1789 (por barrete) quando tinha 30 anos, depois, vereador em 1790, e juiz em 1807, ambas nos pelouros. Era genro de Francisco Xavier Pinto. Na Lista de 1787, aparece casado com Ana Maria Buena, 28 anos, possuidor de escravos. No ano de 1797, figura na Lista Nominativa de Habitantes de Curitiba como capitão, com 38 anos, casado e habitando com ele sua esposa, quatro filhas, uma agregada e cinco escravos.

16. João Antônio da Costa (Guarda Mor) - Natural de Portugal. Foi juiz ordinário por quatro vezes. Em 1789, sua primeira eleição, foi eleito por barrete, em 1790 e 1794 nos pelouros, em 1796 por barrete. Casado com Francisca de Paula Ribas bisneta de Lourenço de Andrade. Na Lista 
Nominativa de Habitantes de Curitiba de 1791, viviam com ele duas filhas, um exposto e 5 escravos. Na Lista do ano de 1793, consta ser senhor de 8 escravos e em 1797, de 14.

17. Joaquim dos Anjos Pereira (Sargento) - Eleito por treze vezes. Sete vezes para procurador, 1791, 1794, 1795, 1803 e 1827, por barrete, e em 1809, 1820, nos pelouros. Quando foi eleito procurador pela primeira vez em 1791, tinha 33 anos. Quatro para vereador, 1795, 1798, 1801 e 1822 (esta última por barrete). Uma para juiz de órfãos em 1819, por barrete. Uma para juiz ordinário em 1810, por barrete, porém não chegou a assumir. Na Lista Nominativa de Habitantes de Curitiba de 1789 consta ter 31 anos.

18. Joaquim Mariano Ribeiro Ribas (Sargento Mor) - Foi eleito quinze vezes para exercer funções na câmara. Duas delas para vereador, em 1784 e 1791 . As outras para juiz ordinário, em 1794, 1798, 1799, 1800, 1802, 1805, 1813, $1814,1818,1819,1821,1822,1825$. Oito delas por barrete, em 1794, 1799, 1800, 1802, 1813, 1818, 1819 e 1822. Destas não assumiu em três ocasiões: 1800, 1818 e 1819. Em 1784, sua primeira eleição, tinha 25 anos. Bisneto de Lourenço de Andrade, casado com Maria Rita Ferreira Bueno, filha de Francisco Xavier Pinto. Na Lista Nominativa de Habitantes de Curitiba de 1793, tinha 35 anos, casado, senhor de 3 escravos e um agregado. Na Lista do ano de 1797, figura com 36 anos, 3 filhos, 4 escravos e 1 agregado.

19. José de Andrade Pereira (Capitão Mor) - Foi por oito vezes eleito para as funções camarárias. Seis vezes para vereador, em 1768, 1816, 1820 e 1823 , nos pelouros, e em 1814 e 1815, por barrete; e duas para juiz ordinário, em 1777 e 1780. Neto de Lourenço de Andrade.

20. José Antônio de Faria Pinto Meneses - Eleito juiz por barrete em 1790. Genro de Lourenço de Andrade, casado com Ana Maria. Segundo a Lista Nominativa de Habitantes de Curitiba de 1787, morava com seu sogro. Na Lista de 1789, não aparece mais nessa situação.

21. José Antônio Mendes Vieira (Capitão) - Natural de Portugal. Quinze vezes foi eleito membro da câmara. Em 1789, 1794, 1795, 1798, 1800, 1802, 1804, $1805,1806,1810,1812,1814,1818,1820$ e 1824 . Oito delas por barrete, em $1794,1798,1800,1802,1804,1812,1806,1820$, mas não assumiu em uma ocasião (1812). Foi vereador em 1789, 1794, 1795, 1798, 1800, 1802, 1804, 1805,1812 e 1814. Nas outras ocasiões foi eleito para a função de juiz ordinário. Em sua primeira eleição em 1789, para vereador, tinha 28 anos. Casado com Maria Ângela Eufrosina Ribas, bisneta de Lourenço de Andrade. Na Lista de 1789, aparece com 28 anos e 5 escravos. Em 1797, com 36 anos, 6 escravos e 3 agregados. 
22. José Nicolau Lisboa (Capitão) - Natural de Portugal. Foi eleito em 1711 e 1714 para funções que não pudemos precisar. Em 1720 exerceu a função de procurador da câmara e em 1736 foi eleito, por barrete, para juiz ordinário.

23. José dos Santos Pacheco Lima - Natural de Portugal. Foi por cinco vezes eleito para exercer funções na câmara. Em 1761, 1769 e 1775 como vereador, e em 1766 e 1788 (esta por barrete) como juiz ordinário. Na Lista Nominativa de Habitantes de Curitiba de 1765, consta ser casado com Maria Pereira da Silva. Tinha 3 filhos, 250 mil reis, 3 armas e 12 escravos.

24. Leão de Mello e Vasconcellos (Capitão Mor) - Natural de Portugal. Eleito cinco vezes para os cargos da câmara. Em 1741 foi eleito, por barrete, vereador; em 1742 saiu para juiz ordinário nos pelouros. No ano de 1743 saiu como procurador nos pelouros e neste mesmo ano foi eleito juiz por barrete, tendo exercido as duas funções. Em 1744 foi eleito juiz ordinário novamente.

25. Luís Gomes da Silva - Treze vezes eleito. Três vezes vereador: 1798 e 1810 por barrete e em 1813 nos pelouros; quatro como procurador: em $1801 \mathrm{e}$ 1811 nos pelouros, em 1804 e 1807, por barrete; três vezes juiz ordinário: 1815 e 1817 por barrete e em 1816 nos pelouros; três vezes juiz de órfãos: 1818,1819 e 1820 . Na data de sua primeira eleição, em 1798 tinha 36 anos. $\mathrm{Na}$ Lista de 1797, consta ter 32 anos, casado, sem filhos, senhor de 5 escravos e 2 agregados

26. Luís de Souza Meneses (Cabo) - Natural de Portugal. Foi vereador em 1764, 1796 e 1802 (esta por barrete). Na Lista Nominativa de Habitantes de Curitiba de 1792, consta ter 25 anos (sic.), casado com Ana dos Santos, vivia com sua família Antônio Martins Lustosa. Possuía 10 escravos e Antonio Martins Lustosa outros 5.

27. Manoel José de França - Natural da Ilha Terceira. Eleito por seis vezes. Em 1807 e 1811, ambas por barrete, para procurador; em 1816 e 1818 para juiz ordinário; e em 1821 e 1823 para juiz de órfãos.

28. Manoel Teixeira de Oliveira Cardoso (Alferes) - Natural de Portugal. Foi eleito apenas uma vez, por barrete para a função de vereador da câmara no ano de 1807.

29. Miguel Rodrigues Ribas (Capitão) - Eleito por oito vezes para as funções da câmara. Seis como juiz ordinário, em 1729, 1741, 1747 e 1749, nos pelouros, e em 1743 e 1748, por barrete; uma para juiz de órfãos em 1753 e uma para vereador em 1773, por barrete. Genro de Lourenço de Andrade, casado Maria Rodrigues de Andrade.

30. Sebastião Teixeira de Azevedo (Capitão) - Eleito por doze vezes para as funções da câmara municipal. Nos anos de 1743, 1752, 1755 e 1760, foi vereador, sendo eleito por barrete em 1752 e 1760. Foi eleito procurador 
somente por barrete, em 1746, 1750, 1754 (esta última vez não assumiu). Em 1763 e 1767 foi juiz ordinário. Foi eleito juiz de órfãos nos anos de 1768, 1780 e 1783, todas por barrete. Na data de sua primeira eleição, 1743, tinha 33 anos. Na Lista Nominativa de Habitantes de Curitiba de 1776, aparece com 66 anos, casado, vivendo de suas lavouras, senhor de três escravos. Viviam com ele um filho e uma filha. Na Lista Nominativa de Habitantes de Curitiba de 1777, vivia no bairro Barigui, 67 anos, casado, 2 filhos, senhor de 3 escravos. Lista de 1778, 69 anos de idade, senhor de 5 escravos, vivia com a esposa e a filha. Na Lista do ano de 1783, 79 anos, viviam com ele duas filas, uma agregada e seu genro João Batista.

31. Vitorino Teixeira de Azevedo - Eleito por onze vezes. Nos anos de 1736, 1738, 1748, 1753 e 1757 foi vereador. Em 1751, 1757 (esta por barrete) e 1762 foi juiz ordinário. Foi eleito procurador em 1742, 1746 e 1756 (esta por barrete). No ano de 1757 foi vereador e juiz ordinário, mas não pudemos identificar para qual dos cargos foi eleito por barrete. Em sua primeira eleição, 1736, tinha 37 anos. Em 1777 morava no Rocio da Vila de Curitiba, tinha 79 anos, e vivam com ele duas filhas. Na Lista Nominativa de Habitantes de Curitiba de 1778, figura com 81 anos. Na de 1782, com 80 anos. Na de 1783, novamente com 81 anos de idade.

\section{Conclusão}

Com base nas leituras e nos resultados finais de nossa pesquisa, podemos dizer que, apesar de não serem recomendadas pela legislação portuguesa, as eleições de barrete ocorriam freqüentemente, em Curitiba. Constatamos que os oficiais da câmara ou ex-membros foram chamados a se reunir, entre 1693 e 1828, (pelo menos) 225 vezes, e nessas reuniões, ocorreram 314 eleições de barrete, visto que em um mesmo dia poderiam ser realizadas mais de uma votação, para cargos distintos. Foi possível determinar a freqüência dessas eleições e identificar os participantes de algumas delas, especialmente seus responsáveis, bem como os cargos para os quais foram convocadas e os respectivos indivíduos eleitos.

Sabendo também que o principal, e mais comum motivo da convocação de uma eleição de barrete eram as recusas, por parte dos eleitos nos pelouros (mas também nos barretes ${ }^{50}$ ), em exercerem as funções para as quais foram designados, conseguimos determinar, em muitos casos, os motivos dessas recusas. Havia todos os tipos de motivos, pela idade do indivíduo, por alegar não saber ler, por

\footnotetext{
${ }^{50}$ Percebemos nas eleições por barrete um total de 34 recusas.
} 
não poder mais enxergar tão bem, por morar longe e não poder se deslocar para a vila tantas vezes (duas) por semana para as sessões da câmara. No entanto, as mais comuns relacionavam-se a isenções e privilégios, o que, no caso das vilas dos sertões brasileiros acabava por tornar-se um problema, pois culminava com a falta de pessoas aptas a ocupar as funções da governança local, uma vez que as "mais luzidas, abastadas e de maior instrução" achavam-se isentas de servir na govenança se estivessem integradas nas milícias. ${ }^{51}$ Apesar de serem as recusas bastante comuns, existiam também casos de pessoas impedidas de exercerem tais funções, no mais das vezes, giravam em torno de processos a que respondiam os eleitos, viagens que estes estavam realizando ou viriam a realizar. ${ }^{52}$

As recusas e impedimentos foram fatores facilitadores na repetição dos indivíduos nos cargos da câmara no período estudado. Para um período de 135 anos no qual deveriam exercer as funções da governança um número próximo de 816 pessoas, verificamos a constante reeleição de um montante de 338 indivíduos. Mais especificamente quanto às eleições de barrete, temos: para um total de 314 eleições, 170 indivíduos eleitos. Desses, 96 indivíduos o foram apenas uma vez; 40 , duas vezes; 13 , três vezes; 6 , quatro vezes; 7 , cinco vezes; 3 , seis vezes; 1 , sete vezes; e 4, oito vezes. Contudo, esse é um universo aproximado de indivíduos envolvidos, pois do mesmo modo que não pudemos identificar muitos dos participantes das vereações, também não pudemos identificar alguns envolvidos no processo de eleição de barrete, tanto eleitos (ou substituídos) quanto votantes, posto que não aparecem seus nomes ou cargos nos autos.

Percebe-se também que, apesar de ser proibido pelas Ordenações Filipinas que um mesmo indivíduo ocupasse cargo na câmara em anos seguidos, a reduzida expressão dos grupos de elegíveis implicava que o exercício dos cargos recaísse em quem já os desempenhara anteriormente. Os indicados nas eleições de barrete eram comumente os homens que ocuparam os cargos nos anos imediatamente anteriores ao da eleição em questão, sendo o intervalo

51 Em 27 de janeiro de 1810 a Câmara de Paranaguá enviou uma Representação ao Príncipe Regente pedindo que este tomasse providências a respeito da falta de pessoas aptas a exercerem as funções da governaça local. A respeito dessa Representação, o Aviso régio de 24 de março de 1810, informa que não havendo pessoas para ocupar os cargos da Câmara, deveriam ser chamados os milicianos, independentemente dos privilégios de que gozavam. SANTOS, Antonio Vieira dos. Memória Histórica de Paranaguá. Paranaguá: Instituto Histórico e Geográfico de Paranaguá, 2001. Vol. 01, p. 215 - 216.

52 SANTOS, Rosângela Maria Ferreira dos. Eleições Municipais no Brasil Colonial: Curitiba, 1735 - 1765. Curitiba, 2002. Monografia (Bacharelado em História) Universidade Federal do Paraná. 
determinado legalmente de três anos entre dois mandatos, nem sempre era respeitado. ${ }^{53}$

Para podermos arriscar algumas conclusões quanto à qualidade das pessoas que ocuparam as funções camarárias entre os anos de 1693 e 1828 ativemo-nos aos 31 indivíduos anteriormente relacionados. Portanto, através da interpretação das informações coligidas referentes aos indivíduos constantes de nossa relação, estabelecemos, o que esperamos ser, para a composição da Câmara Municipal de Curitiba no século XVIII, um paradigma geral de análise.

O estabelecimento desta relação de nomes não esgotou o interesse de nossa pesquisa, ao contrário, foi necessário que explorassemos as diversas questões que ela suscitou. Assim, sendo um de nossos objetivos definir a trajetória pública dos indivíduos, julgamos ter particular importância a determinação dos cargos ocupados pelos camaristas, em especial aquele para o qual foram eleitos pela primeira vez. Nesse sentido, constatamos que dos 31 indivíduos relacionados, 21 foram eleitos para vereador, 5 para procurador e 4 para juiz ordinário. Para um dos camaristas não foi possível determinar qual a primeira função assumida. Dos 21 eleitos para vereador, 12 o foram nos pelouros e 9 por barrete; daqueles eleitos para procurador apenas 1 foi eleito nos pelouros, sendo os outros 4 , por barrete; dos juizes ordinários, 1 saiu nos pelouros e 3 por barrete.

Pudemos também observar a idade com que esses homens eram eleitos pela primeira vez. Foram 3 os eleitos com idade entre 20 e 29 anos, sendo todos eleitos para a função de vereador e nos pelouros; 9 entre 30 e 39 anos, sendo 6 para vereador (três nos pelouros e três por barrete), 2 para procurador, ambos por barrete e um para juiz ordinário, por barrete; 2 foram eleitos com idades entre 40 e 49 anos, ambos por barrete, um para vereador e outro para procurador; foram 2 também os eleitos entre 50 e 59 anos, ambos nos pelouros, um para vereador e outro por barrete. Contudo permaneceram 14 indivíduos para os quais não foi possível determinar a idade aproximada da primeira eleição e um para o qual não encontramos dados que nos revelassem idade ou cargo de sua primeira eleição. Desses 14 indivíduos, 10 foram eleitos para vereador, 5 nos pelouros e 5 por barrete; 1 eleito para procurador, por barrete e 3 eleitos para juiz ordinário, 1 por pelouro e 2 por barrete.

Com relação às funções exercidas, podemos dizer que a trajetória política dos indivíduos geralmente começava por volta dos 30 anos de idade com o cargo de vereador. No entanto, observamos que com a mesma idade era possível ser eleito

\footnotetext{
53 MANIQUE, Antonio Pedro. Processos eleitorais e oligarquias municipais nos fins do Antigo Regime. Arqueologia do estado. Comunicações I. Lisboa, História \& Crítica, 1988.
} 
para a função de juiz ordinário. Para exercer a função de procurador era necessário um certo cabedal, pois era preciso responder com os próprios bens, ou com os de um fiador, pela receita da câmara; por essa razão seria mais comum que os indivíduos com mais idade assumissem essa função, como é o caso do nosso único eleito nos pelouros. No entanto, é possível observar duas eleições por barrete de homens por volta dos 30 anos. Para exercer a função de procurador, de certa forma, arriscavam-se os próprios bens, razão adicional de recusas ao cargo e conseqüentemente da eleição por barrete de indivíduos menos indicados, porém também aptos.

Outras duas questões importantes dizem respeito à naturalidade do indivíduo e sua titulação militar. Quanto à naturalidade, apesar de a legislação eleitoral não permitir, devemos salientar a participação de portugueses nos processos eleitorais curitibanos, pois praticamente a metade dos indivíduos de nossa relação apresentam essa condição, ou seja, para um total de 31 relacionados, temos 15 portugueses e 16 sem indicação de origem, que, por essa razão, acreditamos serem naturais do Brasil ou da própria região. Sobre a titulação dos envolvidos nos processos eleitorais municipais, temos a seguinte situação: 19 indivíduos são portadores de títulos militares e 1 é eclesiástico. Dos 19 titulados militarmente, 10 são portugueses e 9 brasileiros, dos 11 indivíduos sem títulos, 7 são brasileiros e apenas 4 portugueses; o eclesiástico é português. Entre os titulados, encontramos 5 Capitães (três portugueses e dois brasileiros), 3 Capitães-mores (um português e dois brasileiros), 3 Sargentos-mores (dois portugueses e um brasileiro), 3 Alferes (um português e dois brasileiros), 1 Comendador (um brasileiro), 1 Guarda-mor (português), 1 Sargento (brasileiro), 1 Tenente (português) e 1 Cabo (português). Nota-se uma relativa importância na detenção de um título militar, como um definidor de status ou de aptidão.

Outro ponto fundamental para o estabelecimento da qualidade dos indivíduos envolvidos na administração municipal é o estudo das relações de parentesco. Treze dos indivíduos de nossa relação apresentam laços de parentesco entre si, dos quais 9 eram brasileiros e 4 portugueses. Dos 9 brasileiros, 5 eram titulados militarmente e 4 não, todos os 4 portugueses eram militares. Para os 18 indivíduos restantes não foi possível definir nenhum tipo de relação, contudo concluímos que a origem dos indivíduos seja fator decisivo e determinante dessa condição, pois dos 18 indivíduos para os quais não foram encontradas relações de parentesco, 11 eram portugueses e 7 brasileiros. Dentre os portugueses, 6 eram portadores de títulos militares, 4 não o eram, e 1 era padre; entre os brasileiros 4 eram portadores de títulos e 3 não o eram. Dessa forma, a naturalidade dos indivíduos que estabeleciam laços de parentesco entre si, se concebermos que esses laços eram formas de fortalecimento político, pode representar certo 
protecionismo dos locais em relação aos indivíduos de origem portuguesa. No âmbito do poder municipal, através da não participação dos portugueses nas famílias locais, os mesmos eram afastados dos círculos de favorecimento e conseqüentemente das funções camarárias.

Com relação aos indivíduos aparentados entre si, sabemos que 11 tinham laços familiares com Lourenço de Andrade. Dos outros dois, 1 era parente de Joaquim Mariano Ribeiro Ribas, e o outro de Francisco Xavier Pinto. Entre os aparentados de Lourenço de Andrade, 2 tinham ligações com outras famílias, um com a família de Francisco Xavier Pinto, e outro com a de Leão de Melo e Vasconcelos.

Como exemplo de relações de parentesco podemos citar; primeiramente, com relação à família Lourenço de Andrade,

- 1 filho do patriarca, Antônio Ribeiro de Andrade (Capitão-mor), casado com uma neta de Leão de Melo e Vasconcelos (Capitão-mor),

- 2 genros, José Antônio de Faria Pinto Meneses e Miguel Rodrigues Ribas (Capitão),

- 3 netos, Antônio José de Andrade, José de Andrade Pereira (Capitãomor), Antônio Teixeira de Freitas (Alferes),

- 1 bisneto Joaquim Mariano Ribeiro Ribas (Sargento-mor), casado com uma filha de Francisco Xavier Pinto (Sargento-mor),

- 2 indivíduos casados com netas suas, Antônio Ferreira dos Santos e Antônio Guedes de Carvalho, e

- outros 2 casados com bisnetas do patriarca, José Antônio Mendes Vieira (Capitão), João Antônio da Costa (Guarda-mor), ambos portugueses.

Restam ainda

- Francisco Xavier Pinto (Sargento Mor), natural de Portugal, sogro de Joaquim Mariano Ribeiro Ribas, e

- Ignácio de Sá Souto Maior (Capitão), também português, genro de Francisco Xavier Pinto.

Acreditamos que havia em Curitiba um número suficiente de pessoas aptas a exercerem as funções camarárias, contudo o que ocorria era um fechamento do acesso a esses cargos. Certamente, para isso contribuía a própria legislação portuguesa que, restringia o número de indivíduos aptos a ocuparem os cargos municipais por intermédio de várias interdições, às quais já nos referimos anteriormente. Com base nos dados por nós coletados e em estudos, como o que Elizabeth Anne Kuznesof realizou, para a região de São Paulo, sobre o papel da família na sociedade a partir do século XVIII, corroboramos nossa formulação 
inicial de que há a formação de uma elite política local, e que esta se perpetua no poder por gerações, restringindo o acesso aos cargos da câmara, através da prática de casamentos intrafamiliares, pois, como constata Kuznesof, os "relacionamentos horizontais - particularmente dentro da elite - aumentaram em freqüência e importância, à medida que o tamanho da arena política e a economia aumentavam incomensuravelmente". ${ }^{54}$ Dessa forma, as famílias da elite, muito menos temerosas do poderia se supor, viam, umas nas outras, possíveis aliadas para "uma maior participação", manutenção e manipulação do poder político. Sendo muitos dos envolvidos na administração local portadores de títulos militares, concluímos pela existência de uma relação unívoca entre títulos honoríficos e militares e as elites políticas locais, ou seja, as principais famílias detinham o monopólio do poder local, na câmara e na administração militar das tropas auxiliares e de ordenanças, ${ }^{55}$ como muito bem exemplifica o caso da família de Lourenço de Andrade, com onze membros (sendo sete deles portadores de títulos militares) exercendo 51 vezes os cargos da câmara.

Dessa forma, no que diz respeito à legislação eleitoral, esta era freqüentemente desrespeitada, de modo a permitir que os envolvidos na política local defendessem interesses pessoais e familiares. Essa situação, como já indicamos, não era necessariamente incompatível com os interesses da Coroa.

\section{Bibliografia}

\section{FONTES}

LEÃO, Ermelino. Dicionário Histórico e Geográfico do Paraná. Curitiba: Emp. Graphica Paranaense, 1926. 7v.

Livro de Atas de Eleições (1748 - 1758) - Manuscrito; Biblioteca da Câmara Municipal de Curitiba.

Livro de Atas de Eleições (1765 - 1827) - Manuscrito; Biblioteca da Câmara Municipal de Curitiba.

NEGRÃO, Francisco. Genealogia Paranaense. Curitiba: Impressora Paranaense, 1926-1950. 6v.

Termos de Posse e Juramento e Atas de Vereações - Documentação transcrita In: NEGRÃO, Francisco. (ed.). Boletins do Archivo Municipal de Curityba.

Curitiba: Câmara Municipal, vols. 01-43, 1906-1929.

\footnotetext{
${ }^{54}$ KUZNESOF, Elizabeth Anne. op. cit. p. 61.

${ }^{55}$ Ver SALGADO, Graça (org.). op. cit.
} 
ORDENAÇÕES FILIPINAS, Livro 1 [1603]. Lisboa: Fundação Calouste Gulbenkian, 1985. (Edição fac-similar da organizada por Cândido Mendes de Almeida; Rio de Janeiro, 1870).

\section{REFERÊNCIAS BIBLIOGRÁFICAS}

ABREU, João Capistrano de. Capítulos de história colonial: 1500-1800 \& Os caminhos antigos e o povoamento do Brasil. Brasília: Editora da Universidade de Brasília, 1982.

ALVES, Odair Rodrigues. O município: dos romanos à Nova Republica. São Paulo: Companhia Editora Nacional, 1986.

ARRUDA, José J., TENGARRINHA, I. M. Historiografia Luso-brasileira contemporânea. Bauru: Edusc, 1999.

AZEVEDO e SILVA, José Manuel. O processo de municipalização na Amazónia. Aspectos particulares da Vila de Vigia. In: VIEIRA, A. O Município no Mundo Português. Funchal: Centro de Estudos de História do Atlântico, 1998.

BICALHO, Maria Fernanda Baptista. O que significa ser cidadão nos tempos coloniais. In: ABREU, Martha; SOIHET, Rachel. Ensino de História: conceitos, temáticas e metodologias. Rio de Janeiro: Casa da Palavra, 2003.

BOSCHI, Caio C. Colonialismo, poder e urbanização no Brasil setecentista. In: Anais do I Colóquio de Estudos Históricos Brasil - Portugal. Belo Horizonte: PUCMG, 1994.

CAPELA, José Viriato; BORRALHEIRO, R. As elites do norte de Portugal na administração municipal $(1750$ - 1834). In: VIEIRA, A. O Município no Mundo Português. Funchal: Centro de Estudos de História do Atlântico, 1998. COELHO, Maria Helena da Cruz. A dinâmica concelhia portuguesa nos séculos XIV e XV. In: Anais do I Colóquio de Estudos Históricos Brasil - Portugal. Belo Horizonte: PUCMG, 1994.

COELHO, Maria Helena da Cruz. MAGAlHÃES, Joaquim Romero. O Poder concelhio: das origens às cortes constituintes. Notas da História Social. Coimbra: Centro de Estudos e Formação Autárquica, 1986.

COELHO, Virginia Aníbal. Autonomias e despotismo: a câmara e a vila de Santarém no reinado de D. José. Câmara Municipal de Santarém, 1993.

FAORO, Raymundo. Os donos do poder: formação do patronato político brasileiro. 7 ed. Porto Alegre: Editora Globo, 1987. 2 v.

FERREIRA, Marieta de Moraes. História oral: um inventário das diferenças. In: Entre-vistas; abordagens e usos da história oral. Rio de Janeiro: Ed. Fundação Getúlio Vargas, 1994. 
GARCIA, Rodolfo. Ensaio sobre a história política e administrativa do Brasil: 1500 - 1810. Rio de Janeiro: Livraria José Olympio Editora, 1975. $2^{\mathrm{a}}$ ed. GOUVÊA, Maria de Fátima Silva. Os homens da governança no Rio de Janeiro em fins do século XVIII e início do XIX. In: VIEIRA, A. O Município no Mundo Português. Funchal: Centro de Estudos de História do Atlântico, 1998. GUREVIČ, Aaron. El Mercador IN: LE GOFF, J. El hombre medieval. [s/l]: Alianza Editorial, [s/d].

INSSA, Maria Helena Cordeiro. Os Louros de Lourenço: Genealogia e vida do Dr. Lourenço Ribeiro de Andrade 1724 - 1799. Curitiba. Monografia (Bacharelado em história) Universidade Federal do Paraná.

KUZNESOF, Elizabeth Anne. A família na sociedade brasileira: parentesco e estrutura social (São Paulo, 1700 - 1890). Revista Brasileira de História. São Paulo, v. 9, n. 17, set/88-fev/89.

LEVI, Giovanni. Usos da Biografia. In: FERREIRA, Marieta de Moraes; AMADO, Janaína (orgs.). Usos e abusos da história oral. Rio de Janeiro: Ed. Fundação Getúlio Vargas, 1996.

LISBOA, João Francisco. Crônica do Brasil colonial: apontamentos para a história do Maranhão. Petrópolis: Editora Vozes, 1976.

MACHADO, Brasil Pinheiro. Problemática da cidade colonial brasileira. História: Questões \& Debates, Curitiba, n. 10. P. 3-23, jun. 1985.

MANIQUE, Antonio Pedro. Processos eleitorais e oligarquias municipais nos fins do Antigo Regime. Arqueologia do estado. Comunicações I. Lisboa, História \& Crítica, 1988.

MARTINS, Romário. História do Paraná. Curitiba: Fundação Cultural de Curitiba, 1995.

MONTEIRO, Nuno Gonçalo. Os Concelhos e as Comunidade. In: História de Portugal. Vol. 04. Antigo Regime. Lisboa: Estampa, 1998(a).

MONTEIRO, Nuno Gonçalo. Poderes Municipais e elites locais (séculos XVIII XIX): estado de uma questão. In: VIEIRA, A. O Município no Mundo Português. Funchal: Centro de Estudos de História do Atlântico, 1998(b).

PEREIRA, Magnus Roberto de Mello.As posturas municipais e o controle do processo edificatório. Monumenta (Posturas Municipais: Curitiba, 1895; Palmeira, 1895; Guarapuava, 1854-1870). Curitiba, v. 2, n. 7, 1999, p. 03-28.

PEREIRA, Magnus Roberto de Mello; SANTOS, Antônio Cesar de Almeida. O poder local e a cidade: a Câmara Municipal de Curitiba, séculos XVII a XX. Curitiba: Aos Quatro Ventos, 2000. 124p.

PRADO Júnior, Caio. Evolução política do Brasil e outros estudos. 4. Ed. São Paulo: Brasiliense, 1963. 
SALGADO, Graça (org.). Fiscais e Meirinhos: a administração no Brasil colonial. Rio de Janeiro: Nova Fronteira, 1985.

SANTOS, Antonio Cesar de Almeida. Para viverem juntos em povoações bem estabelecidas: um estudo sobre a política urbanística pombalina. Curitiba, 1999. Tese (Doutorado em História). Programa de Pós-graduação em História da Universidade Federal do Paraná.

SANTOS, Antônio Cesar de Almeida; PEREIRA, Magnus Roberto de Mello. Para o bom regime da República: ouvidores e câmaras municipais no Brasil colonial. Monumenta (Provimentos do ouvidor Pardinho para Curitiba e Paranaguá, 1721). Curitiba: Aos Quatro Ventos, v. 3, n. 10, 2001, p. 1-26.

SANTOS, Antônio Cesar de Almeida; SANTOS, Rosângela Maria Ferreira dos (org.). Eleições da Câmara Municipal de Curitiba (1748 a 1827). Monumenta. Curitiba: Aos Quatro Ventos, 2003.

SANTOS, Antonio Vieira dos. Memória Histórica de Paranaguá. Paranaguá: Instituto Histórico e Geográfico de Paranaguá, 2001. Vol. 01

SANTOS, Rosângela Maria Ferreira dos. Eleições Municipais no Brasil Colonial: Curitiba, 1735 - 1765. Curitiba, 2002. Monografia (Bacharelado em História) Universidade Federal do Paraná.

SOARES, Sérgio Cunha. Aspectos da política municipal pombalina: a Câmara de Viseu no reinado de Dom José. Revista Portuguesa de História, T.21. Faculdade de Letras da Universidade de Coimbra, 1984.

SOUZA, Laura de Mello e. Desclassificados do ouro: a pobreza mineira no século XVIII. 2.ed. Rio de Janeiro: Edições Graal, 1982.

VIANA, Francisco José de Oliveira. Populações meridionais do Brasil \& Instituições políticas brasileiras. Brasília: Câmara dos deputados, 1982.

VIDIGAL, Luis. Tipificação da Oligarquia local da vila de Portimar (1755 1834) - problemas processos e fontes. Arqueologia do Estado (Jornadas sobre formas de organização e exercício dos poderes na Europa do sul nos séculos XIII - XVIII). Lisboa: História \& Crítica, 1988.

VIDIGAL, Luis. No microcosmo social português: uma aproximação comparativa à anatomia das oligarquias camarárias do fim do Antigo Regime político (1750 - 1830). In: VIEIRA, A. O Município no Mundo Português. Funchal: Centro de Estudos de História do Atlântico, 1998.

VIDIGAL, Luis. O Municipalismo em Portugal no século XVIII. Lisboa: Horizonte, 1989.

WEHLING, Arno. Atividade judiciária das câmaras municipais na colônia - nota prévia. In: Anais do I Colóquio de Estudos Históricos Brasil - Portugal. Belo Horizonte: PUCMG, 1994. 